\title{
REFUGEES AND THE REGIONAL DYNAMICS OF PEACEBUILDING
}

\begin{abstract}
James Milner*
This article examines the relationship between refugees and the regional dynamics of peacebuilding. It argues that recent approaches to peacebuilding have adopted a narrow understanding of conflict. The article outlines the links between protracted refugee situations and regional insecurity to argue that the relationship between peacebuilding and refugees goes beyond repatriation. Instead, the presence of "spoilers" within the refugee-populated areas, the potential for early and forced repatriation, and the politicization of refugees while in exile have all the proven potential to undermine peacebuilding efforts, while the experience of exile may enable refugees to contribute to the peacebuilding process.
\end{abstract}

\section{Introduction}

A striking feature of discussions on conflict management in recent years has been an emerging consensus on the importance of "peacebuilding". As illustrated by cases as diverse as Afghanistan, Burundi, Liberia, and Haiti, armed conflict has the potential to re-emerge and become more protracted if active steps are not taken to build a "durable peace". While the importance of postconflict reconstruction has been recognized for more than fifty years, the broader notion of peacebuilding became the focus of particular interest in the early 1990s

\footnotetext{
* James Milner, Assistant Professor, Deparument of Political Science, Carleton University, Canada. This article draws on previous research undertaken by the author under the auspices of "The PRS Project: Towards Solutions to Protracted Refugee Situations", University of Oxford, available at: http://www.prsproject.org (last visited 12 Feb. 2009), and the United Nations University (UNU) project "Protracted Refugee Situations: Political, Security and Human Rights Implications". Elements of this article are previously appeared in G. Loescher and J. Milner, Protracted Refugee Situations: Domestic and Security Implications, Adelphi Paper No. 375, London, Routledge, 2005; G. Loescher, J. Milner, E. Newman and G. Troeller, "Protracted refugee situations and the regional dynamics of peacebuilding", Conflict. Security and Development, 7(3), 2007; and G. Loescher and J. Milner, "A framework for responding to protracted refugee situations", in G. Loescher, J. Milner, E. Newman and G. Troeller (eds.), Protracted Refugee Situations: Political, Human Rights and Security Implications, Tokyo, UNU Press, 2008. The author is especially grateful to Gil Loescher for his ongoing support and encouragement.

1 See C. Crocker, F. Osler Hampson and P. Aall (eds.), Turbulent Peace: The Challenges of Managing International Conflict, Washington, DC, US Institute of Peace, 2001.

2 See T. Ali and R. Matthews (eds.), Durable Peace: Challenges for Peacebuilding in Africa, Toronto, University of Toronto Press, 2004
} 
when it was highlighted in the UN Secretary-General's report "An Agenda for Peace". 3 Since then, there have been numerous conceptual and institutional developments, including the establishment of the United Nations (UN) Peacebuilding Commission (PBC) in late 2005. While debates on definitions persist, recent discussions have generally revolved around developing ways to ensure stability in countries previously affected by conflict so as to prevent a slide back into war.

Much of this debate has, however, focused exclusively on peacebuilding activities within the country in question, with little or no attention paid to the regional nature of conflict and the regional dynamics that should consequently be addressed as part of a successful peacebuilding programme. This is especially striking given the growing literature on the regional nature of conflict and insecurity in the global South. As argued by Ayoob, ${ }^{4}$ Buzan, ${ }^{5}$ and others, intrastate conflict in the global South has the demonstrated potential to "spillover" into neighbouring, and equally vulnerable states, thereby regionalizing conflict. For example, civil conflict in Sierra Leone and Burundi not only affected these two countries but also other countries in the Mano River Union in West Africa and the Great Lakes region of Central Africa as a result of the proliferation of small arms and the movement of armed elements across borders. These aspects of conflict have the demonstrated potential not only to spread conflict to neighbouring countries, but also to undermine conflict management and peacebuilding activities in the country of origin.

Refugee movements also have the demonstrated potential to regionalize conflict. ${ }^{6}$ In fact, refugees are to be found in some of the world's poorest and most unstable regions, and originate from some of the world's most fragile states, such as Afghanistan, Burundi, Liberia, Myanmar (Burma), Sierra Leone, Somalia, and Sudan. Just as conflicts in the countries of origin have become protracted, some two-thirds of refugees in the world today are trapped in protracted refugee situations. Such situations - often characterized by long periods of exile, stretching to decades for some groups - constitute a growing challenge for the global refugee protection regime and the international community. Refugees trapped in these situations often face significant restrictions on a wide range of rights, while the continuation of these chronic refugee problems also frequently gives rise to a number of political and security concerns for countries of origin, host states, and states in the region.

3 See UN Secretary-General, An Agenda for Peace: Preventive Diplomacy, Peacemaking and Peace-keeping, Report of the Secretary-General pursuant to the statement adopted by the Summit Meeting of the Security Council on 31 Jan. 1992, $\mathrm{N} / 47 / 227,17$ Jun. 1992.

4 M. Ayoob, The Third World Security Predicament: State Making, Regional Conflict and the International System, Boulder, CO, Lynne Rienner, 1995.

5 B. Buzan, "Third world regional security in structural and historical perspective", in B. Job (ed.), The Insecurity Dilemma: National Security of Third World States, Boulder, CO, Lynne Reinner, 1992.

6 See Loescher and Milner, Protracted Refugee Situations, ap cit;; and G. Loescher, Refugee Movements and International Security, Adelphi Paper 268, London, Brassey's for the International Institute for Strategic Studies, 1992. 
This article considers the regional dynamics of peacebuilding by examining the relationship between protracted refugee situations, and regional insecurity. The article begins by considering the focus of peacebuilding policy and research, especially as it is reflected in the work of the UN PBC; and the extent to which this approach adopts a narrow understanding of conflict, and consequently a narrow understanding of peacebuilding. The article then provides an overview of the growing significance of protracted refugee situations and their links to a broader range of peace and security concerns, to argue that the link between peacebuilding and refugees goes beyond the repatriation of refugees. Instead, the article argues that the presence of "spoilers" within the refugee-populated areas, the possibility of early and forced repatriation by the country of asylum, and the politicization of refugees while in exile, all have the proven potential to undermine peacebuilding efforts, whereas the experience of exile may enable refugee to contribute to various stages of the peacebuilding process. The article concludes by considering the importance of incorporating these regional dynamics into broader policy and research debates on peacebuilding.

\section{Peacebuilding: institutional innovations}

In his 1992 report, "An Agenda for Peace", UN Secretary-General Boutros Boutros-Ghali argued that the end of the Cold War presented new challenges and opportunities for both the international community and international institutions mandated with the preservation of peace and security. In considering the various tools at the disposal of the UN in responding to the new security environment, the Secretary-General added "peacebuilding" to the more established activities of preventive diplomacy, peacemaking, and peacekeeping. $\mathrm{He}$ argued that such an innovation was required as the UN system needed to develop the capacity to "stand ready to assist in peacebuilding in its differing contexts: rebuilding the institutions and infrastructures of nations torn by civil war and strife; and building bonds of peaceful mutual benefit among nations formerly at war".

While few of these activities were new, it became increasingly recognized that these longer term undertakings were essential elements in preventing a return to conflict. The importance of peacebuilding was clearly illustrated by several cases through the 1990 s, including Liberia, Rwanda, and Sudan, ${ }^{8}$ however, numerous gaps remained in the conceptual and practical understanding of peacebuilding. In particular, there has been significant debate on the scope of peacebuilding activities and who should undertake them. ${ }^{9}$ While there is growing empirical evidence to suggest that effective peacebuilding strategies

\footnotetext{
UN Secretary-General, An Agenda for Peace, op. cit., para. 15.

$s$ See Ali and Matchews, Durable Peace, op. cit.

9 A. Cutter, "Peace building: a literature review", Development in Practice, 15(6), 2005.
} 
should involve long-term activities designed to support the security, political, economic, justice, and reconciliation needs of a country emerging from conflict, ${ }^{10}$ no single international organization had the mandate to undertake this full range of activities. While the UN system contained a number of specialized agencies with mandates to undertake some of these activities, and while these agencies have been involved with peacebuilding activities around the world for some time, it became increasingly clear that stronger leadership and institutional coherence were required to ensure that peacebuilding was more effectively and systematically undertaken.

The establishment of a UN PBC was subsequently proposed as a means of ensuring better leadership and coordination of peacebuilding activities within the UN system. ${ }^{11}$ While the establishment of the PBC is a potentially significant institutional development for peacebuilding, it is important to note the limited scope of the early work of the PBC. ${ }^{12}$ Specifically, the early work of the PBC has focused exclusively on activities within the country in question, with little or no attention paid to either the regional nature of conflict or the significant refugee populations associated with these conflicts. In Sierra Leone, for example, the PBC has focused on youth employment and disempowerment; justice and security sector reform; democracy consolidation and good governance; and capacity building, especially the capacity of government institutions. In the case of Burundi, the PBC has focused on promoting good governance, strengthening the rule of law, security sector reform, and ensuring community recovery. While these are important peacebuilding initiatives in both cases, they do not take into account either the significant refugee populations associated with these countries or the broader regional dynamics that have affected conflict and have the potential to undermine peacebuilding. The treatment of these and similar cases by the $\mathrm{PBC}$, and the sustained political and donor interest this is hoped to generate, could provide a unique opportunity for engaging the full spectrum of stakeholders required to formulate and implement a comprehensive solution, not only for peacebuilding and post-conflict recovery in the country of origin but also to resolve the related refugee situations and regional causes of conflict.

The emerging practice of the $\mathrm{PBC}$, however, does not appear to make this link. Instead, the members of the Commission seem to be adopting a countryspecific approach. Such an approach does not allow for a full consideration of factors outside the country that could upset post-conflict recovery. It also denotes a limited understanding of the links between long-term displacement and peacebuilding, incorporating the issue of refugees only insofar as the return and

10 See T. Ali and R. Matthews, "The long and difficult road to peace", in Ali and Matthews (eds.), Durable Peace, op. cit., 409-22.

11 A detailed description and assessment of the PBC is provided in William O'Neill's arcicle in this issue of the Refugee Survey Quarterly.

12 This section is based on interviews conducted in New York in May and Dec. 2006 and in Mar. 2007. 
reintegration of refugees is taken to be a barometer of the success of peacebuilding efforts.

While this is an important dimension of the issue, such a limited approach risks not only missing the opportunity to resolve protracted refugee situations, but also excludes from the work of the PBC a range of factors that could potentially undermine peacebuilding efforts. Refugee-populated areas in the neighbouring states may harbour elements that seek to undermine peacebuilding in the region, especially when underlying political tensions still exist and reconciliation has not been fully achieved. Refugee populations may be drawn into a campaign of destabilization. For example, elements opposed to the peace process in Burundi remained active in western Tanzania for several years after the end of the conflict. These groups drew support from the refugee camps, through taxation, recruitment, and drawing on humanitarian resources. In this way, it is problematic to assume that refugees remain passively in neighbouring countries, awaiting the opportunity to return. Instead, there are many instances where large and protracted refugee situations, left unaddressed, have the potential to undermine the consolidation of a peace process.

Likewise, the concerns of host countries and the limitations on their willingness to host refugees must be taken into account. If the concerns of host states relating to the potentially negative impact of the prolonged presence of refugees on their territory are not addressed, host states may pursue early and coerced repatriation, placing fragile institutions in the country of origin under significant strain and further undermining peacebuilding efforts. For example, between 1993 and 2006, Tanzania frequently claimed that the prolonged presence of Burundian refugees had a negative economic, environmental, and security impact. In response to what it saw as a limited and unpredictable donor response to address these concerns, the Tanzanian government pressed for the repatriation of refugees to Burundi. Many UN and NGO officials in both Dar es Salaam and Bujumbura were concerned about the nature of this repatriation, feeling that refugees were being returned to areas that were unable to adequately receive them, and that the scale of the repatriation risked undermining peacebuilding efforts in Burundi. Given these dynamics, and their potential impact on peacebuilding activities, it is important to consider the growing significance of protracted refugee situations, their causes, and their links to regional security.

\section{The growing challenge of protracted refugee situations}

In June 2004, the Office of the UN High Commissioner for Refugees (UNHCR) defined a protracted refugee situation as,

one in which refugees find themselves in a long-lasting and intractable state of limbo. Their lives may not be at risk, but their basic rights and essential economic, social and psychological needs remain unfulfilled after years 
in exile. A refugee in this situation is often unable to break free from enforced reliance on external assistance. ${ }^{13}$

In identifying the major protracted refugee situations in the world, the UNHCR used the "crude measure of refugee populations of 25,000 persons or more who have been in exile for five or more years in developing countries". ${ }^{14}$ These figures exclude Palestinian refugees who fall under the mandate of the UN Relief and Works Agency for Palestine Refugees in the Near East (UNRWA). Applying this definition to the UNHCR refugee statistics from the end of 2004, there were thirty-three protracted refugee situations, totalling $5,691,000$ refugees, at the start of 2005, as presented in Table 1, below.

In outlining the scope and scale of the problem, the UNHCR also recognized that refugees are spending longer periods in exile and that a greater proportion of the world's refugees are now in situations of prolonged exile. It estimated that "the average duration of major refugee situations, protracted or not, has increased from 9 years in 1993 to 17 years at the end of $2003 "{ }^{15}$ With a global refugee population of over 16.3 million at the end of 1993, 48 per cent of the world's refugees were in protracted situations. More than a decade later, with a global refugee population of 9.2 million at the end of 2004, over 64 per cent of the world's refugees were in protracted refugee situations.

As illustrated by the UNHCR statistics in Table 1, these situations are to be found in some of the most volatile regions in the world. In fact, protracted refugee populations originate from the very states whose instability lies at the heart of chronic regional insecurity. The bulk of refugees in these regions Somalis, Sudanese, Burundians, Liberians, Iraqis, Afghans, and Burmese come from countries where conflict and persecution have persisted for years. In this way, the rising significance of protracted refugee situations is closely associated to the growing phenomenon of so-called "fragile states", since the end of the Cold War. ${ }^{16}$ While there is an increasing recognition that international security planners must pay closer attention to these countries of origin, it is important to also recognize that resolving refugee situations must be a central part of any solution to long-standing regional conflicts, especially given the porous nature of these countries' borders and the tendency for conflict in these regions to engulf their neighbours. In this way, it is essential to recognize that protracted refugee situations are closely linked to the phenomenon of fragile states, have political causes, and therefore require more than simply humanitarian solutions.

An increasing number of host states respond to protracted refugee situations by pursuing policies of containing refugees in isolated and insecure refugee

13 UNHCR, "Protracted Refugee Situations", Standing Committee, 30th Meeting, EC/54/SC/CRP.14, 10 Jun. 2004, 1.

14 Ibid., 2.

15 UNHCR, "Protracted Refugee Situations", op. cit., at para. 6.

16 See G. Loescher and J. Milner, "Understanding the problem of protracted refugee situations" in Loescher et al., Protracted Refugee Situations, op cit. 
Table 1. Major protracted refugee situations: 1 January $2005^{17}$

\begin{tabular}{llr}
\hline Country of asylum & Origin & End-2004 \\
\hline Algeria & Western Sahara & 165,000 \\
Armenia & Azerbaijan & 235,000 \\
Burundi & Democratic Republic of Congo & 48,000 \\
Cameroon & Chad & 39,000 \\
China & Vietnam & 299,000 \\
Congo & Democratic Republic of Congo & 59,000 \\
Côte d'Ivoire & Liberia & 70,000 \\
Democratic Republic of Congo & Angola & 98,000 \\
Democratic Republic of Congo & Sudan & 45,000 \\
Egypt & Occupied Palestinian Territory & 70,000 \\
Ethiopia & Sudan & 90,000 \\
Guinea & Liberia & 127,000 \\
India & China & 94,000 \\
India & Sri Lanka & 57,000 \\
Islamic Republic of Iran & Afghanistan & 953,000 \\
Islamic Republic of Iran & Iraq & 93,000 \\
Kenya & Somalia & 154,000 \\
Kenya & Sudan & 68,000 \\
Nepal & Bhutan & 105,000 \\
Pakistan & Afghanistan (UNHCR estimate) & 960,000 \\
Rwanda & Democratic Republic of Congo & 45,000 \\
Saudi Arabia & Occupied Palestinian Territory & 240,000 \\
Serbia and Montenegro & Bosnia and Herzegovina & 95,000 \\
Serbia and Montenegro & Croatia & 180,000 \\
Sudan & Eritrea & 111,000 \\
Thailand & Myanmar & 121,000 \\
Uganda & Sudan & 215,000 \\
United Republic of Tanzania & Burundi & 444,000 \\
United Republic of Tanzania & Democratic Republic of Congo & 153,000 \\
Uzbekistan & Tajikistan & 39,000 \\
Yemen & Somalia & 64,000 \\
Zambia & Angola & 89,000 \\
Zambia & Democratic Republic of Congo & 66,000 \\
Total & & $5,691,000$ \\
\hline & & \\
& & \\
& &
\end{tabular}

camps, typically in border regions and far from the governing regime. Many host governments now require the vast majority of refugees to live in designated camps, and place significant restrictions on refugees seeking to leave the camps, either for employment or educational purposes. This trend, recently termed the "warehousing" of refugees, ${ }^{18}$ has significant human rights and economic implications. As argued by the UNHCR, "most refugees in such

17 This table refers to refugee situations where the number of refugees of a certain origin within a particular country of asylum has been 25,000 or more for at least five consecutive years. Industrialized countries are not included. Data does not include Palestinian refugees under UNRWA's mandate. Source: UNHCR, The State of the World's Refugees: Human Displacement in the New Millennium, Oxford, Oxford University Press, 2006, 107.

18 See M. Smith, "Warehousing refugees: A denial of rights, a waste of humanity", World Refugee Survey 2004, Washington, US Commitree for Refugees and Immigrants, 2004. 
situations live in camps where idleness, despair and, in a few cases, even violence prevails. Women and children, who form the majority of the refugee community, are often the most vulnerable, falling victim to exploitation and abuse." ${ }^{19}$ More generally, the prolonged encampment of refugee populations has led to the violation of a number of rights contained in the 1951 UN Convention relating to the Status of Refugees, including freedom of movement and the right to seek wage-earning employment.

Faced with these restrictions, refugees become dependent on subsistencelevel assistance, or less, and lead lives of poverty, frustration, and unrealized potential. Containing refugees in camps prevents their presence from contributing to regional development and state-building. ${ }^{20}$ In cases where refugees have been allowed to engage in the local economy, it has been found that refugees can "have a positive impact on the [local] economy by contributing to agricultural production, providing cheap labour and increasing local vendors' income from the sale of essential foodstuffs". ${ }^{21}$ When prohibited from working outside the camps, refugees cannot make such contributions.

Unresolved refugee situations represent a significant political phenomenon as well as a humanitarian problem. Protracted refugee situations often lead to a number of political and security concerns for host countries, countries of origin, regional actors, and the international community. Host states and states in regions of refugee origin frequently argue that protracted refugee situations result in a wide range of direct and indirect security concerns. ${ }^{22}$ The "direct threats" faced by the host state, posed by the spillover of conflict and the presence of "refugee warriors", ${ }^{23}$ are by far the strongest link between refugees and conflict. Here, there are no intervening variables between forced migration and violence as the migrants themselves may be actively engaged in armed campaigns typically, but not exclusively, against the country of origin. Such campaigns have the potential of regionalizing the conflict and dragging the host state into what was previously an intra-state conflict. Armed groups played a significant role in regionalization of the conflict in Africa and Asia during the Cold War. With the end of the Cold War, the logic has changed, but the relevance of refugee warriors remains. This relevance was brought home with particular force in the maelstrom of violence that gripped the Great Lakes region of Central Africa between 1994 and 1996.

19 UNHCR, Africa Bureau, "Addressing Protracted Refugee Situations", paper prepared for the Informal Consultations on New Approaches and Partnerships for Protection and Solutions in Africa, Geneva, Dec. $2001,1$.

20 See K. Jacobsen, "Can refugees benefit the state? Refugee resources and African statebuilding", Journal of Modern African Studies, 40(4), 2002.

21 UNHCR, "Economic and Social Impact of Massive Refugee Populations on Host Developing Countries, as well as Other Countries", EC/54/SC/CRP.5, 18 Feb. 2004, 3.

22 For a more detailed discussion of direct and indirect security concerns related to refugee movements, see J. Milner, Refugees, the State, and the Politics of Asylum in Africa, Basingstoke, Palgrave Macmillan, forthcoming.

23 See A. Zolberg, A. Suhrke and S. Aguayo, Escape from Violence: Conflict and the Refugee Crisis in the Developing World, Oxford, Oxford University Press, 1989, 275-78. 
The outbreak of conflict and genocide in the Great Lakes region of Central Africa in the early 1990 s serves as a clear example of the potential implications of not finding solutions for long-standing refugee populations. Tutsi refugees who fled Rwanda between 1959 and 1962 and their descendants filled the ranks of the Rwandan Patriotic Front (RPF), which invaded Rwanda from Uganda in October 1990. Many of these refugees had been living in the subregion for over thirty years. In the aftermath of the Rwandan genocide, it was widely recognized that the failure of the international community to find a lasting solution for the Rwandan refugees from the 1960s was a key factor that put in motion the series of events that led to the genocide in 1994. According to the UNHCR, "the failure to address the problems of the Rwandan refugees in the 1960 s contributed substantially to the cataclysmic violence of the $1990 \mathrm{~s}$ " ${ }^{24}$ Some fifteen years after the 1994 genocide, it would appear as though this lesson has yet to be learned, as dozens of protracted refugee situations remain unresolved in highly volatile and conflict-prone regions.

The security consequences for host states and regional actors are real. They include cross-border attacks on both host states and countries of origin, attacks on humanitarian personnel, refugees, and civilian populations. Direct security concerns can also lead to serious bilateral and regional political and diplomatic tensions. Cross-border flows are perceived by host states to impinge on their national sovereignty, especially given the tenuous control that many central governments in the developing world have over their border regions. Finally, the activities of armed elements among refugee populations not only violate refugee protection and human rights principles, but also can constitute threats to international peace and security. For example, the training and arming of the mujahidden in the refugee camps in Pakistan during previous decades underscores the potential threat to regional and international security posed by refugee warriors.

More difficult to identify, but just as potentially destabilizing as direct threats, refugee movements may pose "indirect threats" to the host state. Indirect threats may arise when the presence of refugees exacerbates previously existing intercommunal tensions in the host country, shifts the balance of power between communities, or causes grievances among local populations. At the root of such security concerns is the failure of international solidarity and burden sharing with host countries. Local and national grievances are particularly heightened when refugees compete with local populations for resources, jobs, and social services, including health care, education, and housing. Refugees are sometimes seen as a privileged group in terms of services and welfare provisions or as the cause of low wages in the local economy and inflation in local markets. Refugees are also frequently scapegoats for a breakdown in law and order in both rural and urban areas.

24 UNHCR, The State of the World's Refugees: Fiffy Years of Humanitarian Action, Oxford, Oxford University Press, 2000, 49. 
Furthermore, it has been argued that "in countries which are divided into antagonistic racial, ethnic, religious, or other groupings, a major influx can place precariously balanced multi-ethnic societies under great strain and may even threaten the political balance of power". ${ }^{25}$ In this way, the presence of refugees has been demonstrated to accelerate "existing internal conflicts in the host country". ${ }^{26}$ This concern was made most explicitly clear in Macedonia's reluctance to accept Kosovar Albanian refugees in March 1999, citing the concern that the mass of Kosovar Albanian refugees "threatened to destabilise Macedonia's ethnic balance". ${ }^{27}$ Other examples include the arrival of Iraqi Kurds in Turkey, of Afghan Sunni Muslims in Shia-dominated Pakistan, or of Pashtun Afghans in Beluchi-dominated Beluchistan. ${ }^{28}$

But, not all refugees are seen as threats. The question of which refugees are seen as threats, and why, may be partially explained by understanding the perception of refugees as members of the local political community or as outsiders. Indeed,

in the Third World, the remarkable receptivity provided to millions of Afghans in Pakistan and Iran, to ethnic kin from Bulgaria in Turkey, to Ethiopians in the Sudan, to Ogadeni Ethiopians in Somalia, to southern Sudanese in Uganda, to Issaq Somali in Djibouti and to Mozambicans in Malawi has been facilitated by the ethnic and linguistic characteristics they share with their hosts. ${ }^{29}$

In this sense, the importance of affinity and shared group identity cannot be overstated. If a host community perceives the incoming refugee as "one of us", then positive and generous conceptions of distributive justice will apply.

Conversely, if the refugees are seen as members of an "out-group", they are likely to receive a hostile reception. In cases where there is a division along ethnic, linguistic, or religious lines, "a major population influx can place precariously balanced multi-ethnic societies under great strain and may even threaten the political balance of power". ${ }^{30}$ Indeed, refugees, "as an out-group, can be blamed for all untoward activities". ${ }^{31}$ While levels of crime may rise by no more than expected with a comparable rise in population, refugees increasingly are seen as the cause. As argued by Maluwa, the "presence of massive numbers

25 Loescher, Refugee Movements and International Security, op. cit., 42.

26 M. Weiner (ed.), "Security, stability and incernational migration", in International Migration and Security, Boulder, CO, Westview Press, 1993, 16.

27 Macedonian Deputy Foreign Minister, speaking at the Emergency Meeting on the Kosovo Refugee Crisis, Geneva, 6 Apr. 1999.

28 F. Stepputat, Refugees, Security and Development: Current Experience and Strategies of Protection and Assistance in "the Region of Origin", Working Paper No 2004/11, Copenhagen, Danish Institute for International Studies, 2004, 4 .

29 Loescher, Refugee Movements and International Security, op. cit., at 42.

30 Ibid.

31 T. Maluwa, "The refugee problem and the quest for peace and security in southern Africa", International Journal of Refugee Law, 7(4), 1995, 657. 
of refugees" can "create feelings of resentment and suspicion, as the refugee population increasingly, and often wrongly, gets blamed for the economic conditions that may arise within the domestic population". ${ }^{32}$ This can lead to a point where "poverty, unemployment, scarcity of resources, and even crime and disease, are suddenly attributed to the presence of these refugees and other foreigners". ${ }^{33}$

This dynamic has been evident in the dramatic restrictions on asylum that have been imposed by host states in Africa since the mid-1990s. ${ }^{34}$ Numerous reports have pointed to the significance of the absence of meaningful burden sharing and the growing xenophobia in many African countries as the key factors motivating restrictive asylum policies. ${ }^{35}$ There is significant evidence to suggest that as international assistance to refugees is cut, refugees are forced to seek alternative means to survive. This frequently places refugees in conflict with local populations and can even lead them into illegal activities.

Rather ironically, xenophobic sentiments among African populations against refugees

have emerged at a time when most of Africa is democratizing and governments are compelled to take into account public opinion in formulating various policies. The result has been the adoption of anti-refugee platforms by political parties which result in anti-refugee policies and actions by governments. ${ }^{36}$

Just as politicians in western Europe faced increasing pressures to restrict entry as asylum became a significant issue in domestic politics, "the rise of multiparty democracy in Africa... has arguably diminished the autonomy of state elites in determining the security agenda". ${ }^{37}$ A common response to these pressures has been for host states to push for the repatriation of refugees at the earliest possible occasion.

\section{Refugees and the regional dynamics of peacebuilding}

Given these diverse links between protracted refugee situations and state and regional instability, it is striking that the question of refugees has been largely absent from recent debates on peacebuilding. Contemporary policy and research on peacebuilding have generally addressed refugees as a matter of secondary

32 Ibid.

33 Ibid.

34 Sec, Milner, Refugees, the State, and the Politics of Asylum in Africa, op. cit.

35 B. Rutinwa, "The end of asylum? The Changing Nature of Refugee Policies in Africa", UNHCR New Issues in Refugee Research, Working Paper No. 5, Geneva, UNHCR, May 1999; and J. Crisp, "Africa's refugees: Patterns, problems and policy challenges", New Issues in Refugee Research, Working Paper No. 28, Geneva, UNHCR, Aug. 2000.

36 Rutimwa, "The end of asylum?", op. cit., 2.

37 M. Gibney, "Security and the ethics of asylum after 11 September", Forced Migration Review, No. 13, Jun. 2002. 
concern, focusing instead on programmes in the country of origin to consolidate peace and prevent a return to the conflict. Within this approach, the relationship between peacebuilding and refugees is taken to be unidirectional, with the return of refugees seen as a barometer of the extent to which peacebuilding has been successful. This view was recently reinforced by the UN High Commissioner for Refugees, António Guterres. In addressing the UN Security Council in January 2009, the High Commissioner argued that "the scale of return and success of reintegration are two of the most tangible indicators of progress in any peacebuilding process". ${ }^{38}$

These factors are clearly an important dynamic and effective peacebuilding activities must address the needs of refugees by ensuring that the preconditions for successful return and reintegration are present in the refugees' home country. ${ }^{39}$ This often presents significant challenges, especially following a protracted conflict where physical infrastructure, homes, and social services have been destroyed. ${ }^{40}$ As the lessons of the past decade make clear, effective peacebuilding in such contexts should also address a wider range of issues affecting returnees, from justice and reconciliation, housing and property rights, human rights monitoring, to the provision of livelihoods in war-torn economies. Clearly, the reintegration of displaced populations poses a wide range of peacebuilding challenges, many of which fall beyond the mandate of humanitarian agencies such as the UNHCR.

Addressing such challenges should not, however, obscure the fact that the prolonged presence of refugees in neighbouring countries cannot be treated as an isolated factor, to be addressed at the end of the peacebuilding process. As argued by Morris and Stedman, "refugee movements are all too often seen only as a by-product of conflict, with limited attention paid to the various ways they may cause conflict, prolong conflict, or frustrate efforts to resolve conflicts". ${ }^{41}$ In fact, a number of the political and security challenges associated with the prolonged presence of refugees in a region have the proven ability to undermine peacebuilding efforts, including the presence of so-called "spoilers" in refugee populations and pressures from the host country to push for early and unsustainable return. A failure to engage with such regional dynamics has the real potential to undermine peacebuilding efforts within the country of origin.

38 Statement by A. Guterres, United Nations High Commissioner for Refugees, to the United Nations Security Council, New York, 8 Jan. 2009, reproduced in the Documents section of this isste.

39 Sce B. S. Chimni, "Refugees and post-conflict reconstruction: A critical perspective", International Peacekeeping, 9(2), 2002.

40 See S. Ogara, "Introduction: Refugee repatriation and peace-building", Refugee Survey Quarterly, 16(2), 1997, vi-x.

41 E. Morris and S. Stedman, "Protracted refugee situations, conflict and security: The need for better diagnosis and prescription", in Loescher et al, Protracted Refugee Situations, op cit., 82. 


\section{1. "Refugee warriors" as "spoilers"}

The most significant challenge to peacebuilding posed by protracted refugee situations is the presence of so-called "spoilers" in refugee camps or in refugee-populated border areas. Spoilers, understood as "groups and tactics that actively seek to hinder, delay, or undermine conflict settlement", 42 are akin to so-called "refugee warriors", as outlined above.

During the 1970s and 1980s, examples of refugee warrior communities could be found among Afghan mujahidden in Pakistan, the Khmers Rouges in Thailand, and the Nicaraguan Contras in Central America. In Africa, refugee warrior communities were the product of proxy wars in the Horn of Africa and in southern Africa, wars of national liberation, especially in southern Africa, and post-colonial conflicts, especially in the African Great Lakes. Similar dynamics exist in many contemporary conflicts, both in Africa and elsewhere, and constitute a serious challenge to peacebuilding activities. In fact, the presence of spoilers in the refugee-populated areas of neighbouring states have frustrated peacebuilding efforts in conflicts as diverse as Burundi, Liberia, Afghanistan, Myanmar, and Sudan.

In the African Great Lakes, the alleged presence of Burundian armed elements in refugee-populated areas of western Tanzania had a significant impact on prospects of peace in Burundi in recent years. In fact, two of the earliest Burundian rebel groups, Palipehutu and Frolina, were formed by refugees who fled Burundi in 1972. Burundian refugee warrior communities continued to play a role until early 2005 , as refugee camps in Tanzania were widely understood to play a key role in recruitment, fundraising and other activities.

It is widely understood that the best response to the presence of armed elements within a refugee population is through their physical separation and legal exclusion from refugee status, but such an undertaking has consistently proven to be beyond the capability of humanitarian actors, such as the UNHCR. ${ }^{43}$ For example, in the aftermath of the Rwandan genocide and the militarization of refugee camps in the region, the UNHCR called for closer cooperation with regional and international security actors to more effectively address the challenge posed by refugee warriors. More than a decade later, however, broader cooperation within the UN system to deal with the problem of refugee warriors remains problematic, and the militarization of refugee camps and settlements continues to undermine refugee protection, regional security, and peacebuilding efforts in the country of origin.

42 E. Newman and $O$. Richmond, "The impact of spoilers on peace processes and peacebuilding", United Nations University Policy Brief, No. 2, 2006. See also S. Stedman, "Spoiler problems in peace processes", International Security, 22(2), 1997.

43 See: W. O'Neill, "Conflict in West Africa: Dealing with exclusion and separation", International Journal of Refugee Law, 12 (Special Supplementary Issue), 2000; Lawyers' Committee for Human Rights (LCHR), Refugees, Rebels and the Quest for Justice, New York, LCHR, 2002, 171-94. 


\subsection{Push for early and unsustainable repatriation}

A second challenge to peacebuilding posed by protracted refugee situations is the potential for the large-scale repatriation of refugees before the necessary conditions of safety and sustainable return exist in the country of origin. If the concerns of host states relating to the potentially negative impact of the prolonged presence of refugees on their territory are not addressed, host states may pursue early and coerced repatriation, placing fragile institutions in the country of origin under significant strain and further undermining peacebuilding efforts.

The potential for forced and premature return is heightened as donor interest shifts from the host country to the country of origin following the advent of peace. Given that many host states feel that they are unfairly burdened with the great majority of the world's refugees, failure to consider the needs and interests of host states as a part of the broader peacebuilding efforts could exacerbate the concerns of countries of asylum, leading to additional restrictions on asylum and a push for early forced repatriation.

Such concerns were clearly evident in the case of Tanzania in recent years. With the early signs of peace in Burundi, coupled with a significant shift in donor engagement away from the refugee programme in Tanzania in early 2002, the Tanzanian Government began to push for a tripling of the number of refugee repatriations to Burundi. While the UNHCR did not agree to promote repatriation, given the prevailing insecurity in many regions of Burundi, some 85,000 refugees were nevertheless repatriated from Tanzania to Burundi in 2003. The scale of these returns placed a significant strain on the fragile peace in Burundi. Given that these returns coincided with sustained crime and insecurity, additional reductions in food rations, and increased restrictions on refugees' freedom of movement and economic activity in Tanzania, a number of refugee advocates questioned the voluntary nature of the repatriations, suggesting that conditions in the camps in Western Tanzania had become so unbearable that many refugees felt compelled to return to Burundi, notwithstanding the continuing insecurity there.

Similar dynamics have been present elsewhere in Africa and Asia, where donors and host countries all see an interest in pursuing refugee repatriation at the earliest possible opportunity. In many instances, however, such repatriations do not result in a solution to protracted refugee situations, but instead result in a reoccurrence of conflict and future refugee movements as the root causes of flight are often left unaddressed and the preconditions for sustainable return are not ensured. In cases as diverse as Liberian refugees in Guinea, Rohingya refugees in Bangladesh and Afghan refugees in Pakistan, early and unsustainable repatriation did not lead to a durable solution, but instead formed the foundation of renewed refugee movements.

While part of the response to this dynamic is to ensure that the preconditions for repatriation are in place, it is also important to ensure that donor interest does not rapidly shift to peacebuilding in the country of origin at the 
expense of refugee assistance programmes in neighbouring countries. Instead, the interests and concerns of host countries need to be more fully considered as part of the regional dynamics of peacebuilding. Such an approach would not only ensure that host states do not pursue early and unsustainable repatriation, but would also contribute to the rehabilitation of refugee-populated areas in host countries. While the majority of peacebuilding activities must necessarily be focused on the country of origin, any approach to peacebuilding that is not mindful of broader regional dynamics, including the presence of refugees, risks overlooking factors that could undermine peacebuilding efforts. At the same time, it is important to consider how early engagement with refugee populations in neighbouring countries may contribute to peacebuilding in the country of origin.

\subsection{Experience of exile}

While the experience of exile may contribute to the politicization of refugee populations, ${ }^{44}$ thereby undermining prospects for post-repatriation reconciliation, it is also increasingly recognized that refugees can make a significant contribution to peacebuilding in their country of origin. In a statement to the UN Security Council in January 2006, by the UN High Commissioner for Refugees, António Guterres, noted that "refugees return with schooling and new skills... Over and over, we see that their participation is necessary for the consolidation of both peace and post-conflict economic recovery". 45 Thus, refugee contributions may result from particular skills that they acquire in exile that may directly contribute to post-conflict reconstruction, from the direct involvement of refugees in the negotiation of the peace agreement, and through peace education and reconciliation activities that can occur prior to repatriation. For example, special teacher training programmes have been implemented in Kenya to train Sudanese refugees to meet the educational needs both in the Kakuma refugee camps and in South Sudan. ${ }^{46}$

In fact, a wide range of training opportunities can be extended to refugees in prolonged exile that would eventually contribute to ensuring a durable solution to their plight, either through repatriation, local integration, or resettlement in a third country. Opportunities such as language training, vocational training, professional development, peace education, and other activities could all form part of a broader solutions-oriented approach, and contribute to both peacebuilding and the self-reliance of refugees. Notwithstanding the clear benefits of such programmes, they remain difficult to fund. At the same time,

\footnotetext{
44 Sce L. Malkki, Purity and Exile: Violence, Memory and National Cosmology among Hutu Refugees in Tanzania, Chicago, Chicago University Press, 1995.

45 Statement by A. Guterres, United Nations High Commissioner for Refugees, to the United Nations Security Council, 24 Jan. 2006.

46 UNHCR, "New refugee teachers one of the keys to development in Southern Sudan", 29 Jan, 2007, available at: http://www.unher.org/news/NEWS/45be27864.html (last visited 12 Feb. 2009).
} 
host states are generally wary of them and view them as a backdoor to local integration.

Given the potential benefits of such programmes to both peacebuilding and the livelihood of refugees, it is important to address host and donor country concerns and ensure that such programmes become a standing feature of programmes for protracted refugee situations. Programmes to enhance the self-reliance of refugees do not, however, constitute a solution to protracted refugee situations. These short-term interventions can only help to manage the situation until a resolution can be found. In the long term, the implications of protracted refugee situations can only be fully addressed through the formulation and implementation of comprehensive solutions. ${ }^{47}$

\section{Conclusion: towards a more predictable response to refugees and peacebuilding}

This article has argued that there is an important link between protracted refugee situations, regional insecurity and the regional dynamics of peacebuilding. The article began by considering the focus of peacebuilding policy and research, especially as it is reflected in the work of the UN PBC. The article then considered the links between protracted refugee situations and a broader range of peace and security concerns to argue that the link between peacebuilding and refugees goes beyond the repatriation of refugees. The article outlined how the presence of "spoilers" within refugee-populated areas, the potential for early and forced repatriation by the country of asylum, and the politicization of refugees while in exile, all have the proven potential to undermine peacebuilding efforts, while the experience of exile may enable refugee to contribute to various stages of the peacebuilding process. Although additional research is required to understand how these dynamics present themselves in different types of protracted refugee situations, it is clear that their significance cannot be excluded from an effective consideration of the range of factors that contribute to, or undermine, peacebuilding.

Given these links between protracted refugee situations, fragile states, and peacebuilding, it is clear that actions by humanitarian agencies, such as the UNHCR, without the support of peace and security and development actors will lead to neither comprehensive solutions for protracted refugee situations nor an effective response to the peacebuilding implications of prolonged exile. So long as discussions on protracted refugee situations remain exclusively within the humanitarian community, and do not engage the broader peace and security and development communities, they will be limited in their impact.

Despite the need for a multifaceted approach to protracted refugee situations, the overall response of policy makers remains compartmentalized with security, development, and humanitarian issues mostly being discussed in

47 See, Loescher and Milner, "A framework for responding to protracted refugee situations", op. cit. 
different forums, each with their own theoretical frameworks, institutional arrangements, and independent policy approaches. Meaningful comprehensive solutions for protracted refugee situations must overcome these divisions and adopt a new approach that incorporates recent policy initiatives by a wide range of actors. While there remains a significant role for the UNHCR to play as a catalyst for bringing together key stakeholders and for ensuring that the process is sustained, ${ }^{48}$ this type of broader engagement cannot occur without the sustained engagement of all branches of the UN system. In this way, the establishment of the PBC provides both a timely opportunity and a possible institutional context for this type of cross-sectoral approach.

The composition and mandate of the $\mathrm{PBC}$ places it in a unique position to address a number of these concerns. In fact, the UN General Assembly specifically provided that country-specific meetings of the PBC shall include as additional members the country under consideration (namely, the country of origin), countries in the region (namely, host countries), as well as senior $\mathrm{UN}$ representatives in the field and other relevant $\mathrm{UN}$ representatives (including the UNHCR). ${ }^{49}$ In this way, the PBC represents a unique forum for the coordination of peace and security, development, and humanitarian activities to address both protracted refugee situations and the regional dynamics of peacebuilding.

There is a risk that the emerging response of the PBC, however, will not engage with these broader issues. Indeed, the members of the Commission seem to be adopting a country-specific approach that excludes a consideration of factors outside the country that could upset post-conflict recovery. It also adopts a limited understanding of the links between long-term displacement and peacebuilding. A broader recognition of the role of refugees and the regional dynamics of peacebuilding will be an important precondition for the success of the PBC, especially as it undertakes its country-specific deliberations on Burundi and Sierra Leone. Conflict in both Burundi and Sierra Leone resulted in significant refugee movements into neighbouring countries which, in turn, played a significant role in the course of the conflict. More generally, the conflict in both countries is largely tied to broader regional dynamics and neighbouring conflicts - the African Great Lakes for Burundi and the Mano River Union for Sierra Leone. Given the regional dynamics of conflict and the role of refugee populations not only as a consequence of conflict but also as a source of its perpetuation in both cases, the importance of situating peacebuilding efforts in Burundi and Sierra Leone within a broader regional context would seem logical. The PBC has not, however, adopted such an approach, and its discussions have remained country-specific, with no discussion of the regional dynamics.

\footnotetext{
48 See A. Betts, "Historical lessons for overcoming protracted refugee situations" in Loescher et al., Protracted Refugee Situations, op cit.

49 UNGA res. $60 / 180,30$ Dec. 2005.
} 